\title{
Perancangan dan Analisis dari Automation Gasket Assembling Machine untuk Pengurangan Jumlah Tenaga Kerja
}

\author{
Muhammad Ekka Januar Akbar and Joni Welman Simatupang* \\ Electrical Engineering Study Program, Faculty of Engineering, President University \\ Jl. Ki Hajar Dewantara, Kota Jababeka, Cikarang Baru, Bekasi - Indonesia 17550 \\ Email: ekkajanuar@gmail.com; joniwsmtp@president.ac.id* (corresponding email)
}

\begin{abstract}
ABSTRAK
Proses manufaktur membutuhkan operator untuk melakukan proses perakitan komponen, akan tetapi setiap tahunnya upah minimum operator selalu meningkat, sedangkan peningkatan harga jual produk ke pelanggan tidak sama dengan besarnya peningkatan upah minimum. Oleh sebab itu, manajemen harus berfikir bagaimana dapat menyelesaikan kondisi seperti ini, karena jika tidak diatasi maka perusahaan merugi. Ada minimal tiga cara untuk mengatasi kondisi ini: pertama adalah dengan cara merubah proses manual perakitan komponen menjadi proses otomatis, yang kedua merubah impor komponen dari luar negeri menjadi komponen yang dibuat di negara sendiri, yang ketiga mengubah impor consumable tools dari luar negeri menjadi dibuat dalam negeri. Tulisan ini akan membahas hal yang terkait dengan merubah proses manual pemasangan gasket parts menjadi proses otomatis dengan menggunakan mesin. Mesin ini menggunakan sistem kontrol berbasis programmable logic controller $(P L C)$, di mana semua proses yang dilakukan oleh operator digantikan oleh struktur mekanik sehingga proses ini berubah menjadi proses otomatis. Pada akhirnya, proses otomatis ini mampu mengurangi kebutuhan operator dan memberikan efek terhadap turunnya direct labor cost kurang lebih sebesar Rp. 9,2 juta dalam satu shift/bulan, tetapi nominal ini dapat berubah-ubah tergantung dari total jumlah produk yang dibuat setiap bulannya. Efek lainnya dari perubahan proses menjadi otomatis adalah meningkatnya level kualitas pembuatan produk, hal ini disebabkan karena proses pengecekan dilakukan $100 \%$ oleh sensor, sehingga potensi human error dapat dihilangkan dengan penggunaan full automatic gasket assembling machine.
\end{abstract}

Kata kunci: peningkatan upah, upah minimum rata-rata, proses otomatis, pengurangan operator, penurunan direct labor cost, sistem kontrol PLC.

\begin{abstract}
Manufacturing process need lot of man power for assembling parts process, but every year minimum of basic salary for man power always increase, however price product to customer increase not significant same as basic salary increase. Therefore management must think how to solve this problem, because if there is no counter measure profit, the company will face loss. There are at least three ways to counter measure this condition: first is by changing manual process for part assembling using automation system, second is to get the import parts from local supplier, and third is change import consumable tool to local supplier. This paper will explain about the process and impact of changing manual proses in gasket part assembling to full automatic gasket part assembling with new automatic machine. This machine using programmable logic controller (PLC), where all process which was done by man power will change to mechanical structure, so this process will change to automatic process. At the end, this process can reduce the need for man power and give effect to the reduction of direct labor cost also to be about 9,2 million rupiah in one shift production/month, however this nominal will fluctuate due to the number of total production quantity/month. Anothe effect with the use of automatic machine for quality process level is the increase of product quality level development because all item process check will be done by $100 \%$ sensor check, so the human error factor will be eliminated by using full automatic gasket assembling machine.
\end{abstract}

Keywords: Increasing of salary, average minimum salary, Automation process, man power reduction, decreased of direct labor cost, PLC system control. 


\section{Pendahuluan}

Penelitian ini dilakukan agar dapat mengurangi jumlah operator (Mohamed, 2005) dan meningkatkan level otomasi (Gorlach, 2008) dalam proses produksi starter produk (lihat Gambar 1), khususnya pada proses pemasangan gasket, yaitu dengan cara merubah proses manual pemasangan gasket part ke case bearing part clutch sub assy starter menjadi proses otomatis pemasangan gasket parts ke case bearing part clutch sub assy starter dengan cara membuat full otomatis mesin pemasangan gasket parts ke case bearing part clutch sub assy starter berbasis sistem kontrol PLC (Hendy, 2008). Proses pemasangan gasket parts ini sendiri terdiri dari dua pekerjaan utama, pertama adalah proses pengarahan pin barrel clutch dan yang kedua proses pemasangan gasket parts pada case bearing clutch sub assy starter.

Pada kondisi proses manual (lihat Gambar 2 dan 3), proses untuk melakukan pengarahan pin barrel clutch dan pemasangan gasket parts pada case bearing clutch sub assy starter dilakukan oleh satu orang operator, yaitu dengan cara operator mengambil 3 buah gasket parts dari box parts dan memasangkan parts tersebut ke tiga lubang yang terdapat pada case bearing clutch sub assy part, lalu setelah itu melakukan pengarahan pin barrel clutch sesuai dengan posisi yang ditentukan pada standard operational process (SOP).

Oleh karena itu mesin full otomasi pada pemasangan gasket parts ini dibuat untuk menggantikan proses utama yang dilakukan oleh operator, yaitu melakukan pengarahan pin barrel clutch ke arah yang telah di tentukan pada SOP dengan menggunakan sistem cylinder pneumatic (Sulaeman, 2009) yang dihubungkan dengan sistem rack and gear dan ditransmisikan ke positioning tool yang secara langsung bersentuhan dengan pin barrel clutch untuk selanjutnya pin barrel tersebut diarahkan ke posisi yang telah ditentukan pada SOP dengan cara memutar dummy pin barrel clutch searah dengan jarum jam $(\mathrm{CW})$, langkah selanjutnya adalah melakukan pemasangan 3 buah gasket parts ke tiga lubang yang terdapat pada case bearing clutch sub assy part dengan menggunakan gasket part feeder supply untuk memindahkan gasket parts dari wadah gasket parts kebagian unit rotary mekanik yang selanjutnya akan ditiup oleh udara yang bertekanan agar gasket parts dapat dipindahkan ke bagian nozzle yang telah dihubungkan secara tegak lurus dengan lubang gasket parts pada case bearing clutch sub assy part, untuk mencegah terjadinya not good (NG) terhadap jumlah gasket parts yang dipasang, contohnya gasket part kurang atau tidak masuk pada lubang gasket parts di case bearing clutch sub assy part, yaitu dengan cara menambahkan unit ejector atau pendorong pada nozzle gasket assembling, dan unit sensor pendeteksi gasket part pada bagian rotary unit serta unit sensor pendeteksi gasket part pada bagian case bearing clutch sub assy, serta ada pula sensor pendeteksi posisi pin barrel guna memastikan posisi pin barrel sudah berada pada posisi sesuai dengan SOP.

Tujuan dari penelitian ini adalah :

1. Mengubah proses manual pemasangan gasket part ke case bearing S/A dari proses manual ke proses full otomatis.

2. Merubah proses manual pengarahan pin barrel sejauh $35^{\circ} \pm 5^{\circ}$ dari proses manual ke proses full otomatis.

3. Meningkatkan profit perusahan dengan cara mengurangi operator dalam melakukan suatu proses produksi,

4. Menurunkan not good ratio yang disebabkan oleh human error factor,

5. Dapat menjaga Line Operation Ratio $>87 \%$ dan short stop ratio $<3 \%$ dengan penggunaan full otomasi mesin, minimal dalam 8 jam kerja.

\section{Metode Penelitian}

Gasket assembling, adalah proses pemasangan komponen gasket sebanyak 3 buah ke bagian lubang case bearing dan proses pengarahan komponen dummy pin barrel sejauh $35^{\circ} \pm 5^{\circ}$ atau hingga dummy pin barrel sejajar dengan titik pada case bearing. Sebelumnya proses ini dilakukan secara manual oleh operator, yang kemudian dibuatkan mesin untuk menggantikan proses yang sebelumnya manual menjadi proses yang otomatis dengan menggunakan mesin, yang mana perubahan tersebut akan dibahas pada penelitian ini. 


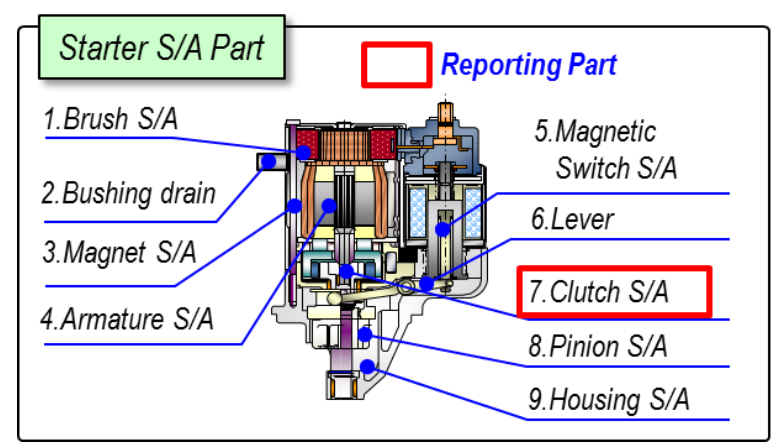

Gambar 1 General starter produk

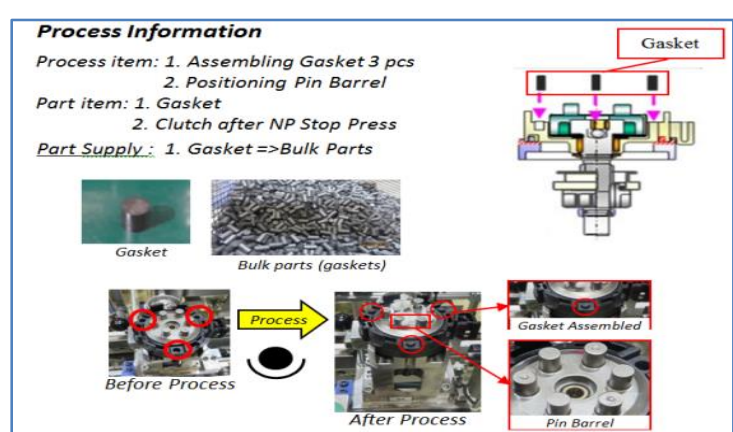

Gambar 2 Informasi proses manual pemasangan gasket parts dan pengarahan pin barrel

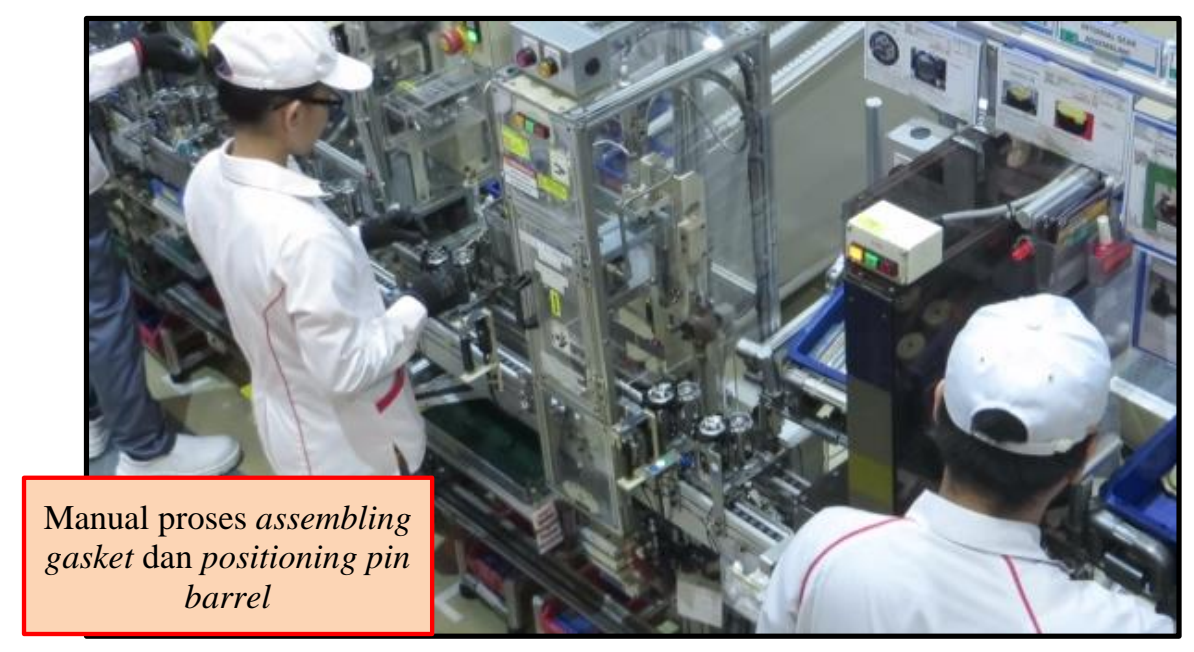

Gambar 3 Manual proses pemasangan gasket part \& pengarahan posisi pin barrel

Gambar 4 merupakan kondisi susunan mesin/layout dan posisi operator clutch and bearing center sebelum proses pemasangan gasket dilakukan secara otomatis, dimana untuk urutan proses yang diwarnai dengan warna biru merupakan proses yang dilakukan secara otomatis dan urutan proses yang berwarna kuning merupakan proses yang dilakukan secara manual.

Terdapat 10/27 proses yang sudah dilakukan secara otomatis dan 17/27 proses yang dilakukan secara manual, dan urutan C21 dengan operator nomor 9 merupakan posisi dari proses gasket assembling.

\subsection{Konsep Dan Spesifikasi Mesin}

Untuk dapat mengubah proses manual pengarahan dummy pin barrel dan pemasangan gasket parts sebanyak 3 buah menjadi otomatis proses maka harus dilakukan perubahan elemen kerja yang sebelumnya dilakukan oleh satu orang operator menjadi pekerjaan aktuator-aktuator yang dapat menggantikan setiap pekerjaan-pekerjaan operator dalam melakukan proses pengarahan dummy pin barrel dan pemasangan gasket parts.

Tabel 1 berikut ini merupakan langkah-langkah pekerjaan/standard working chart dari operator 9 didalam melakukan proses pengarahan dummy pin barrel dan pemasangan gasket parts sebanyak 3 buah.

Sedangkan, Gambar 7 dan 8 menjelaskan tentang desain konsep dan spesifikasi mesin untuk melakukan perubahan aktivitas yang dilakukan oleh operator menjadi aktivitas yang dilakukan oleh sistem aktuator mekanikal yang pergerakannya dikontrol oleh sistem elektrikal. 


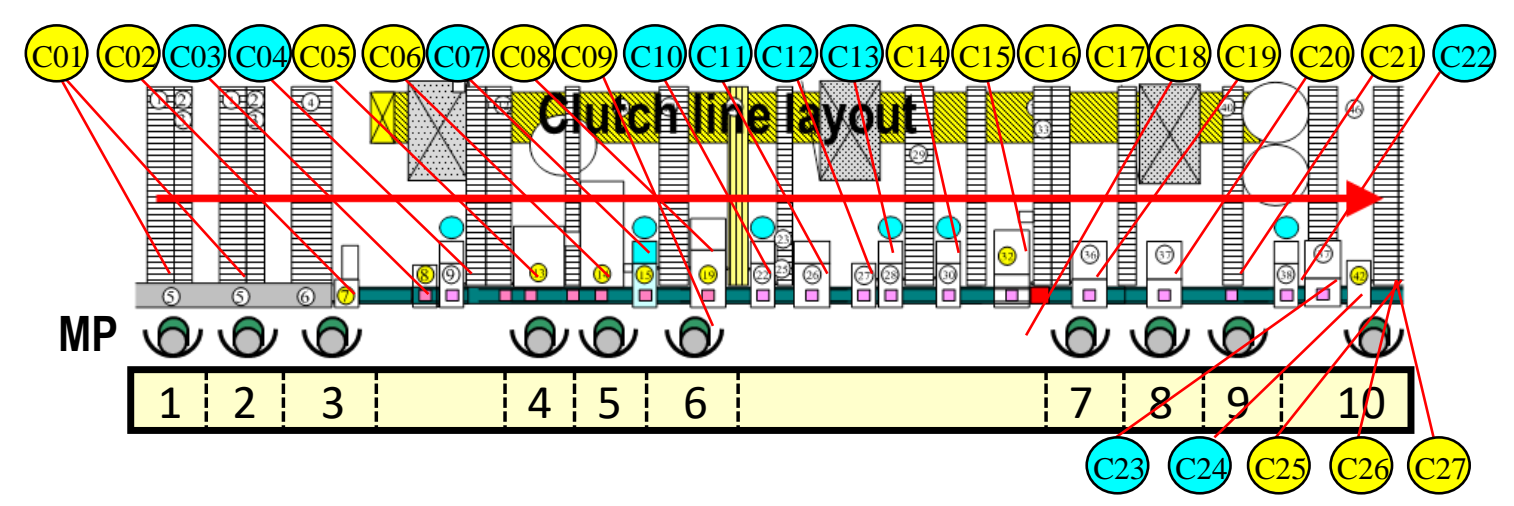

Gambar 4. Proses dan operator layout Clutch line sebelum improvement
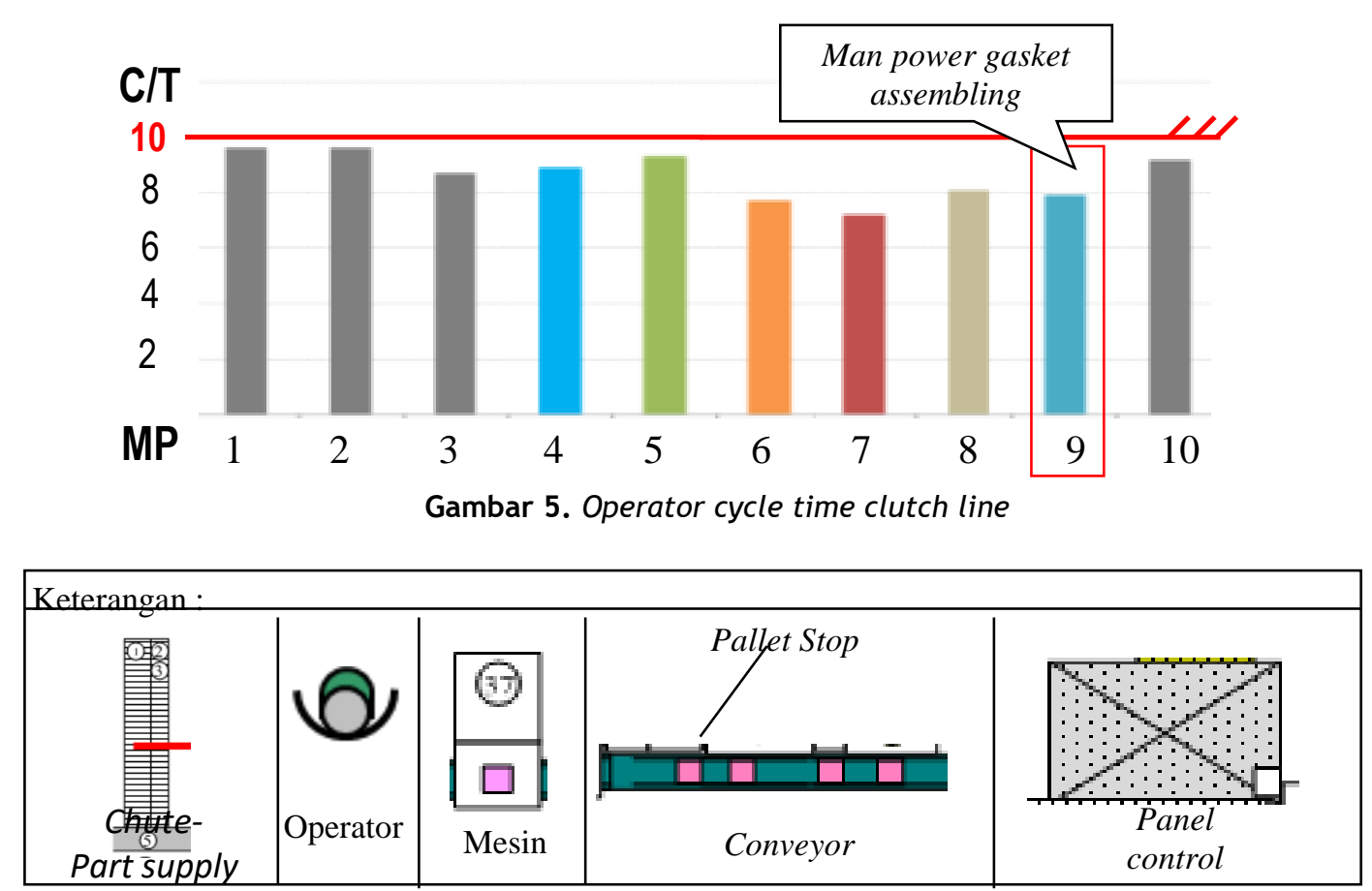

Gambar 6 Keterangan layout Clutch line

Tabel 1. Standard working chart operator 9

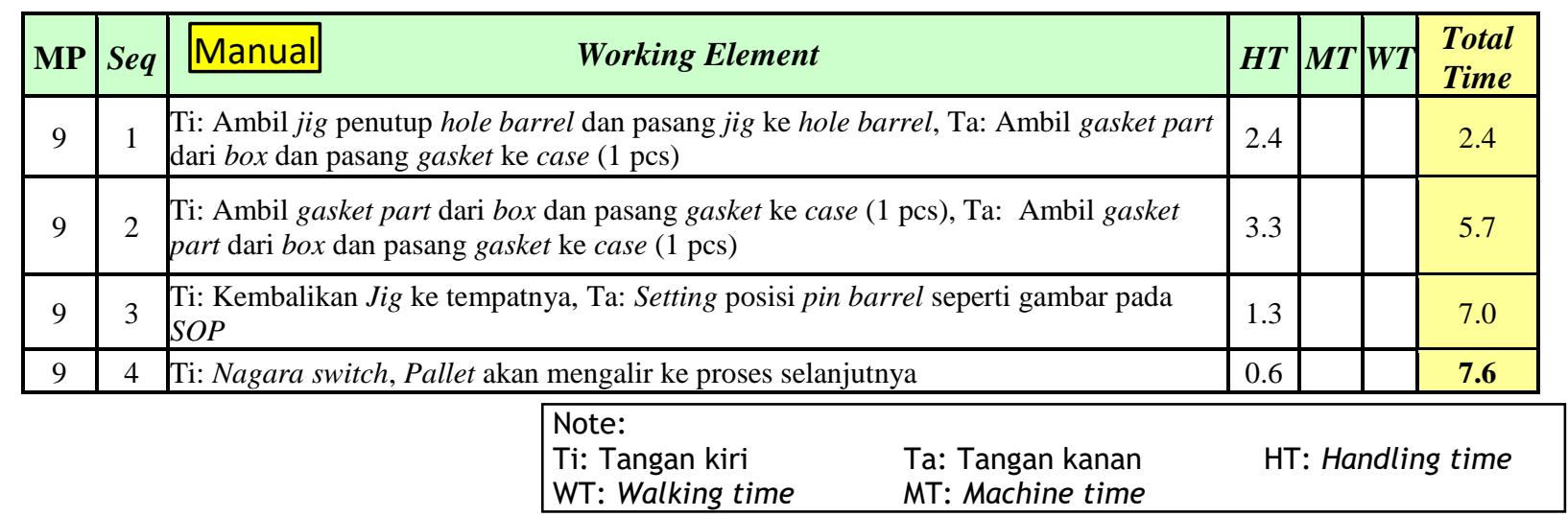




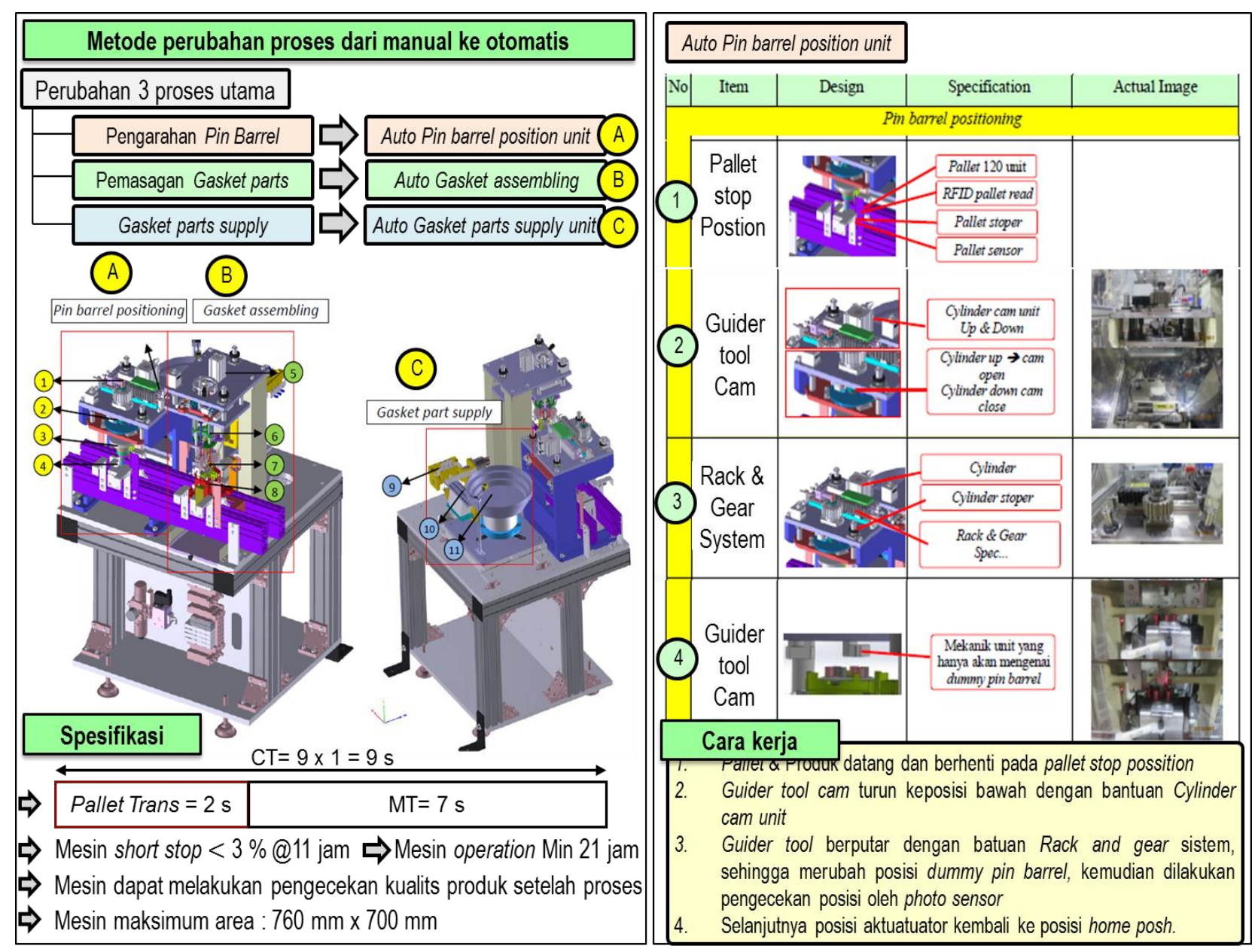

Gambar 7. 3D mesin gasket assembling konsep dan mekanikal pengarahan pin barrel

Gambar 9 menjelaskan perubahan pengecekan kualitas yang sebelumnya dilakukan oleh operator diubah menjadi otomatis, item pengecekannya dilakukan secara otomatis oleh mesin.

\subsection{Meninjau Pembuatan Program Mesin}

Setelah seluruh pekerjaan operator digantikan oleh mekanikal aktuator, maka langkah selanjutnya adalah membuat desain kontrol untuk mengatur pergerakan mekanikal aktuator secara otomatis.

Langkah yang dilakukan adalah membuat flow chart dari sistem yang akan dibangun, dan selanjutnya dibuatkan time chart dimana terdapat dua buah flow chart dan time chart. Gambar 10 dan 11 merupakan flow chart dan time chart untuk proses pengarahan pin barrel, sedangkan untuk Gambar 12 dan 13 merupakan flow chart dan time chart untuk proses pemasangan gasket part (Hendy, 2008 ; Sulaeman, 2009).

Pada Gambar 10 terdapat time chart dari proses pengarahan pin barrel, dimana pada time chart tersebut menggambarkan aktuator B yaitu Cylinder Pallet mulai bergerak maju meninggalkan posisi home posh (B+) dan kondisi relay 1 (R1) aktif pada saat sensor Ph1, Px1 dan Ls7 aktif, sehingga pada saat kondisi stroke cylinder maksimum akan mengaktifkan sensor Ls5, dan saat R1, sensor Ls5 dan Ls7 aktif serta pembacaan data dari RFID yang ada di pallet produk dinyatakan sama dengan data RFID yang ada di mesin maka kondisi ini akan memberikan perintah kepada cylinder cam guide untuk bergerak ke bawah menuju produk (C-). 

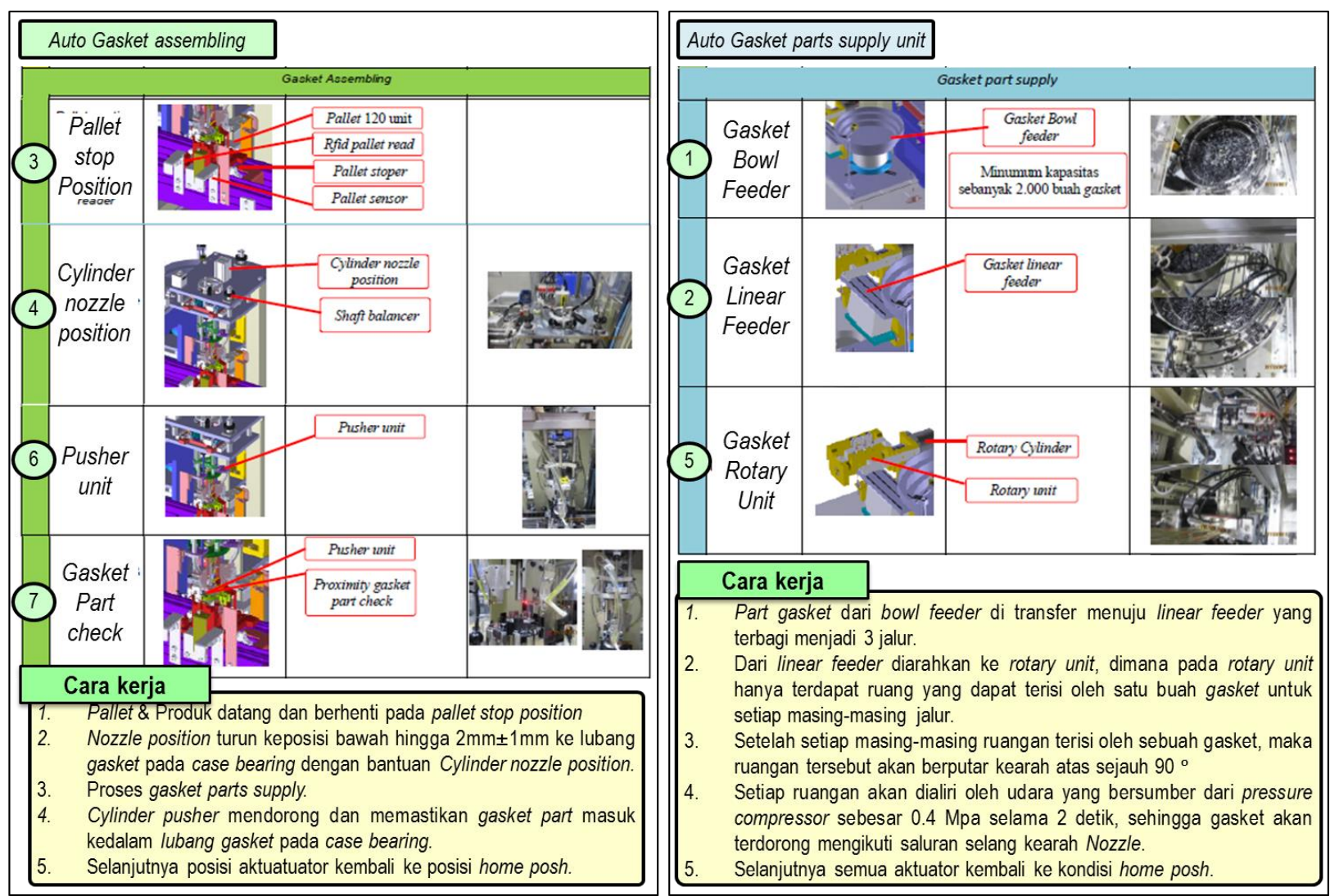

Gambar 8. Mekanikal gasket assembling

\begin{tabular}{|c|c|c|c|c|c|c|c|c|c|}
\hline \multirow{3}{*}{$\begin{array}{c}\text { Process } \\
\begin{array}{c}\text { Centering } \\
\text { process }\end{array}\end{array}$} & \multicolumn{2}{|c|}{ Changing point } & \multirow{2}{*}{ Concern point } & \multicolumn{4}{|c|}{ Correspondence } & \multirow{2}{*}{\multicolumn{2}{|c|}{$\begin{array}{l}\text { Check } \\
\text { results }\end{array}$}} \\
\hline & \multirow{2}{*}{\begin{tabular}{|c|} 
Before \\
Positioning Manual \\
\end{tabular}} & \begin{tabular}{|r|} 
After \\
\end{tabular} & & \multicolumn{2}{|r|}{ Occurrence } & \multicolumn{2}{|c|}{ Flow out } & & \\
\hline & & Full auto & Miss position & $\mathrm{M} / \mathrm{C}$ & Stopper pin cylinder & $\mathrm{M} / \mathrm{C}$ & Sensor auto switch & $\begin{array}{c}\text { M/C } \\
\text { Check }\end{array}$ & OK \\
\hline \multirow[t]{4}{*}{$\begin{array}{c}\text { Gasket } \\
\text { Assembling }\end{array}$} & \multirow[t]{4}{*}{ Manual } & \multirow[t]{4}{*}{ Full auto } & $\begin{array}{l}\text { Gasket at pin } \\
\text { hole barrel }\end{array}$ & $\mathrm{M} / \mathrm{C}$ & Shaft centering & OPR & Armature can't Assy & $\begin{array}{l}\text { Max } \\
\text { Try }\end{array}$ & OK \\
\hline & & & $\begin{array}{l}\text { Gasket less/ } \\
\text { More than } 3 \text { pcs }\end{array}$ & $M / C$ & Sensor part check & $\mathrm{M} / \mathrm{C}$ & Camera check & $\begin{array}{c}\text { Max } \\
\text { Try }\end{array}$ & OK \\
\hline & & & $\begin{array}{l}\text { Gasket not } \\
\text { assembly } \\
\text { perfectly }\end{array}$ & $\mathrm{M} / \mathrm{C}$ & Shaft pusher & $\mathrm{M} / \mathrm{C}$ & Camera check & $\begin{array}{l}\text { Max } \\
\text { Try }\end{array}$ & OK \\
\hline & & & Skip process & $\mathrm{M} / \mathrm{C}$ & $\begin{array}{l}\text { Pallet stopper } \\
\text { \& ID }\end{array}$ & $\mathrm{M} / \mathrm{C}$ & $\begin{array}{l}\text { Prevent flow out } \\
\text { by pallet ID }\end{array}$ & $\begin{array}{l}\text { M/C } \\
\text { Check }\end{array}$ & OK \\
\hline \multirow{2}{*}{$\begin{array}{l}\text { Dandory } \\
\text { assembly } \\
\text { position }\end{array}$} & Manual (visual) & \multirow{2}{*}{$\begin{array}{l}\text { Selector Nozzle } \\
\text { (nd) }\end{array}$} & \multirow{2}{*}{ Miss Type } & \multirow[t]{2}{*}{$M / C$} & \multirow[t]{2}{*}{ MC Alarm } & \multirow[t]{2}{*}{ Part } & \multirow{2}{*}{$\begin{array}{l}\text { Part Can't } \\
\text { Assembly }\end{array}$} & \multirow{2}{*}{$\begin{array}{l}\text { M/C } \\
\text { Check }\end{array}$} & \multirow[t]{2}{*}{$\mathrm{OK}$} \\
\hline & For next model & & & & & & & & \\
\hline $\begin{array}{l}\text { Gasket } \\
\text { Supply }\end{array}$ & Bulk Part & $\begin{array}{c}\text { Part Feeder } \\
3 \\
25\end{array}$ & $\begin{array}{l}\text { Gasket less caused } \\
\text { empty feeder }\end{array}$ & $\mathrm{M} / \mathrm{C}$ & Machine alarm & $\mathrm{M} / \mathrm{C}$ & Camera check & $\begin{array}{l}\mathrm{M} / \mathrm{C} \\
\text { Check }\end{array}$ & OK \\
\hline
\end{tabular}

Gambar 9. Proses quality confirmation

Pada saat posisi stroke mencapai maksimum maka akan mengaktifkan Ls1, sehingga pada saat Ls1, Ls4,Ls7 dan R1 aktif kondisi ini akan memberikan perintah kepada cylinder rack \& gear untuk bergerak meninggalkan home posh (D+) pada saat ini dimana proses pengarahan pin barrel berlangsung, setelah posisi stroke cylinder ( $\mathrm{D}+$ ) mencapai maksimal maka akan mengaktifkan Ls2, sehingga pada saat Ls2, Ls5, Ls7 dan R1 aktif maka akan memberikan perintah kepada cylinder cam guide untuk bergerak kembali menuju home posh dan kembali mengaktifkan Ls0, dimana pada saat kondisi Ls0, Ls5, Ls7 dan R1 aktif kondisi ini akan memberikan perintah kepada cylinder rack \& gear untuk bergerak kembali menuju home posh (D-) sehingga kembali mengaktifkan Ls3 Pada saat Ls3 aktif dan sensor Ph3 aktif dan saat kondisi Ph3 aktif ini menandakan posisi pin barrel sudah berada 
pada posisi yang sesuai dengan standar, maka mesin akan memberikan data ke pallet produk melalui RFID bahwa proses pengarahan pin barrel menghasilkan proses yang OK. Sedangkan apabila kondisi sebaliknya terjadi dimana sensor Ph3 tidak aktif ini menandakan posisi pin barrel setelah pengarahan di luar dari standar sehingga mesin akan memberikan data ke pallet produk melalui RFID bahwa proses pengarahan pin barrel menghasilkan proses yang NG, apabila terjadi NG maka squance akan berhenti dan berubah ke program NG sedangkan apabila hasil OK, maka akan mengaktifkan R2 dan memberikan perintah kepada cylinder pallet untuk bergerak kembali menuju home posh (B-) mengaktifkan Ls4 dam R3 yang selanjutnya memberikan perintah kepada cylinder pallet stopper untuk bergreak turun menjauhi posisi home posh $(\mathrm{A}+)$ sehingga kondisi ini megaktifkan Ls6, dan R3 dimana pada kondisi ini pula pallet produk meninggalkan proses pengarahan pin barrel sehingga sensor Ph1 dan Px1 tidak aktif. Dengan Ph1, Px1 tidak aktif dan Ls6, R3 aktif kondisi ini yang memberikan perintah kepada cylinder pallet stopper untuk bergerak naik kembali ke posisi home posh (A-). Dengan demikian seluruh squance program pengarahan pin dilakukan secara full otomatis, untuk program pemasangan gasket metode yang digunakan sama seperti pada proses pengarahan pin barrel.

Pada beberapa squance control harus di tambahkan dengan program interlock sehingga perintah untuk aktuator tidak berhenti pada saat sensor sudah tidak aktif lagi karena actuator yg menjadi trigger sudah bergerak meninggalkan home posision, sedangkan untuk menonaktifkan interlock/interlock release dilakukan oleh sequence selanjutnya yang prosesnya sudah selesai dilalui, contoh dari penggunaan interlock digambarkan pada Gambar 11 dan 13.

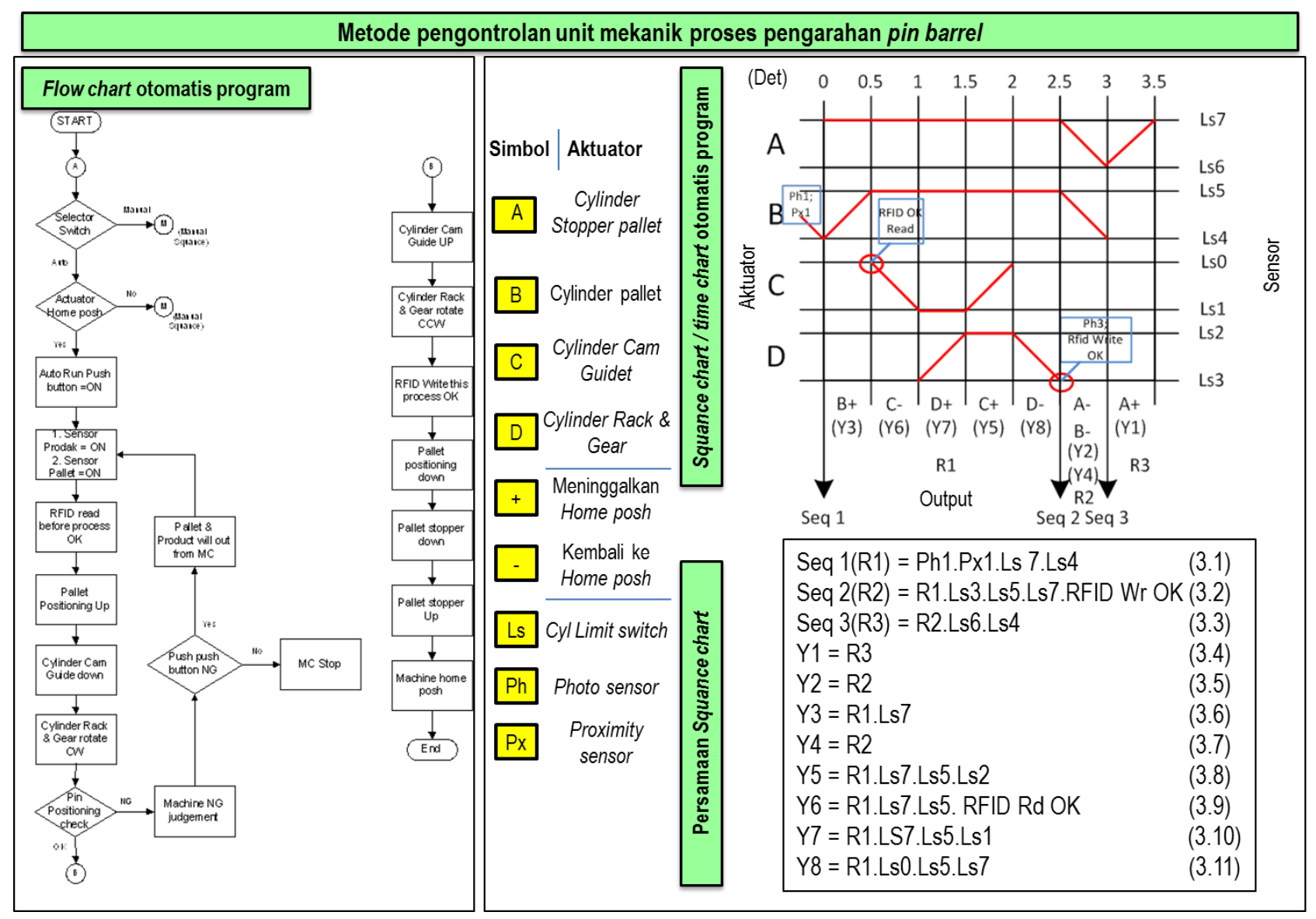

Gambar 10 Flow chart dan time chart pengarahan pin barrel 


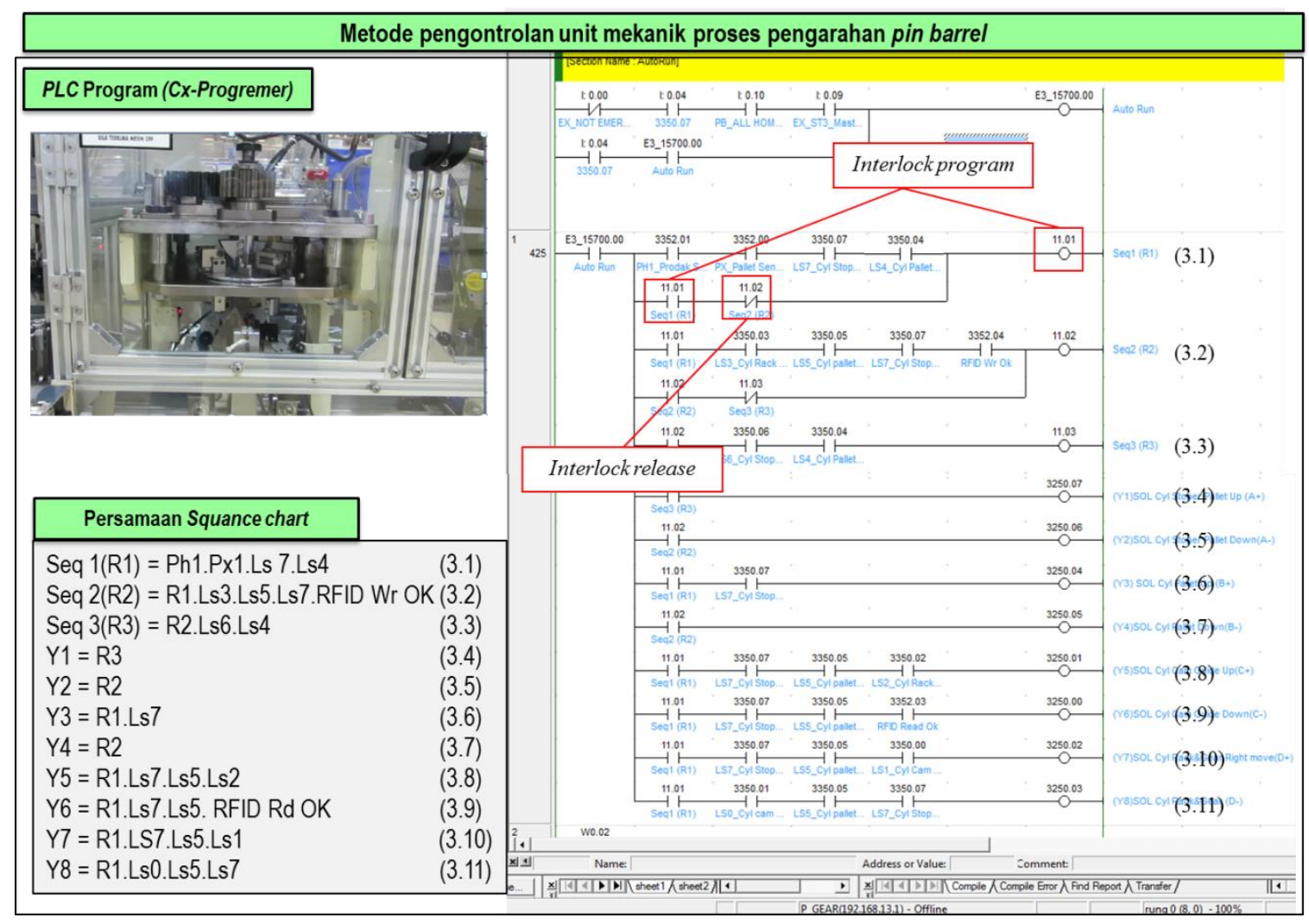

Gambar 11 PLC program otomatis pengarahan pin barrel

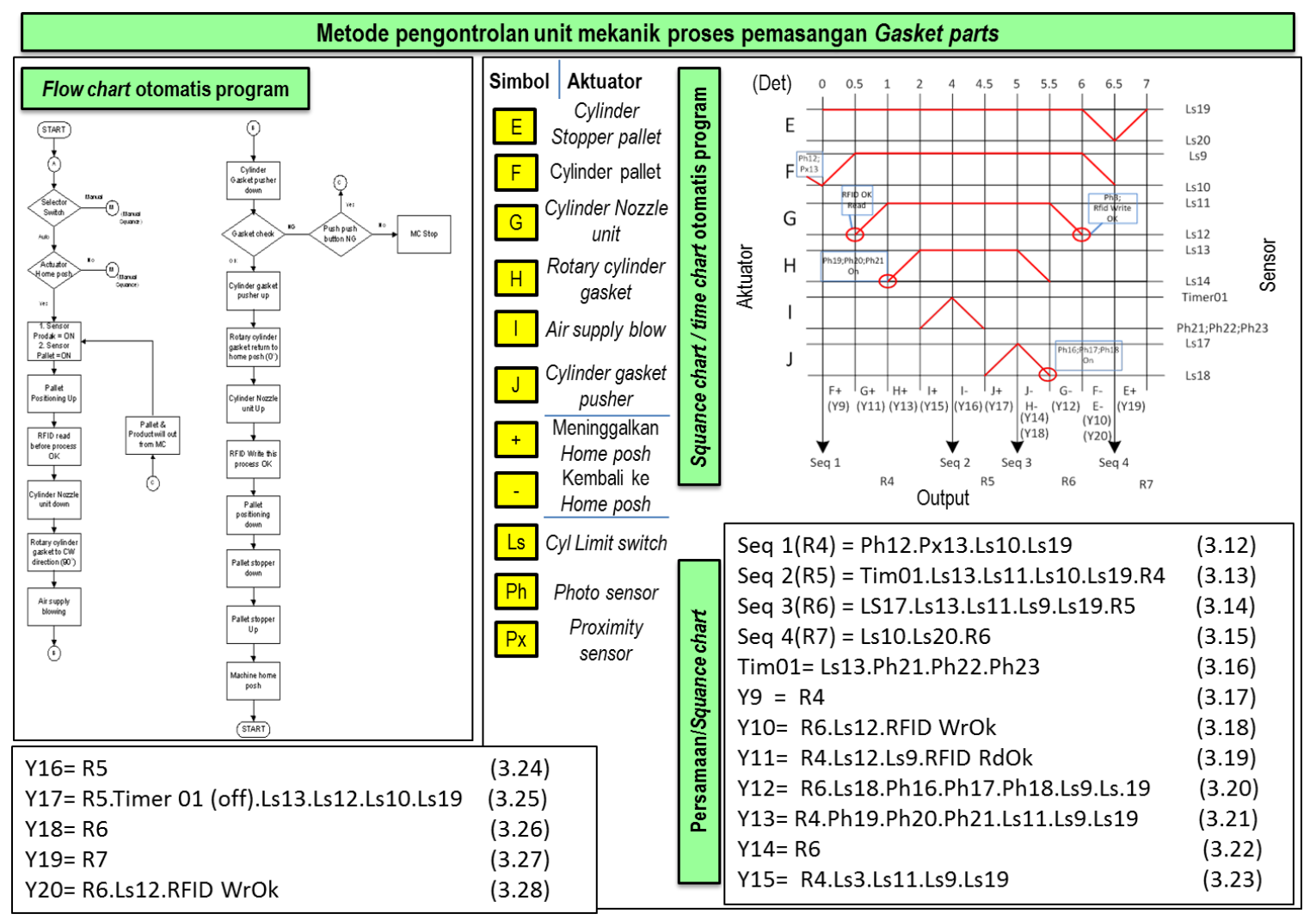

Gambar 12. Flow chart dan time chart pemasangan gasket parts 


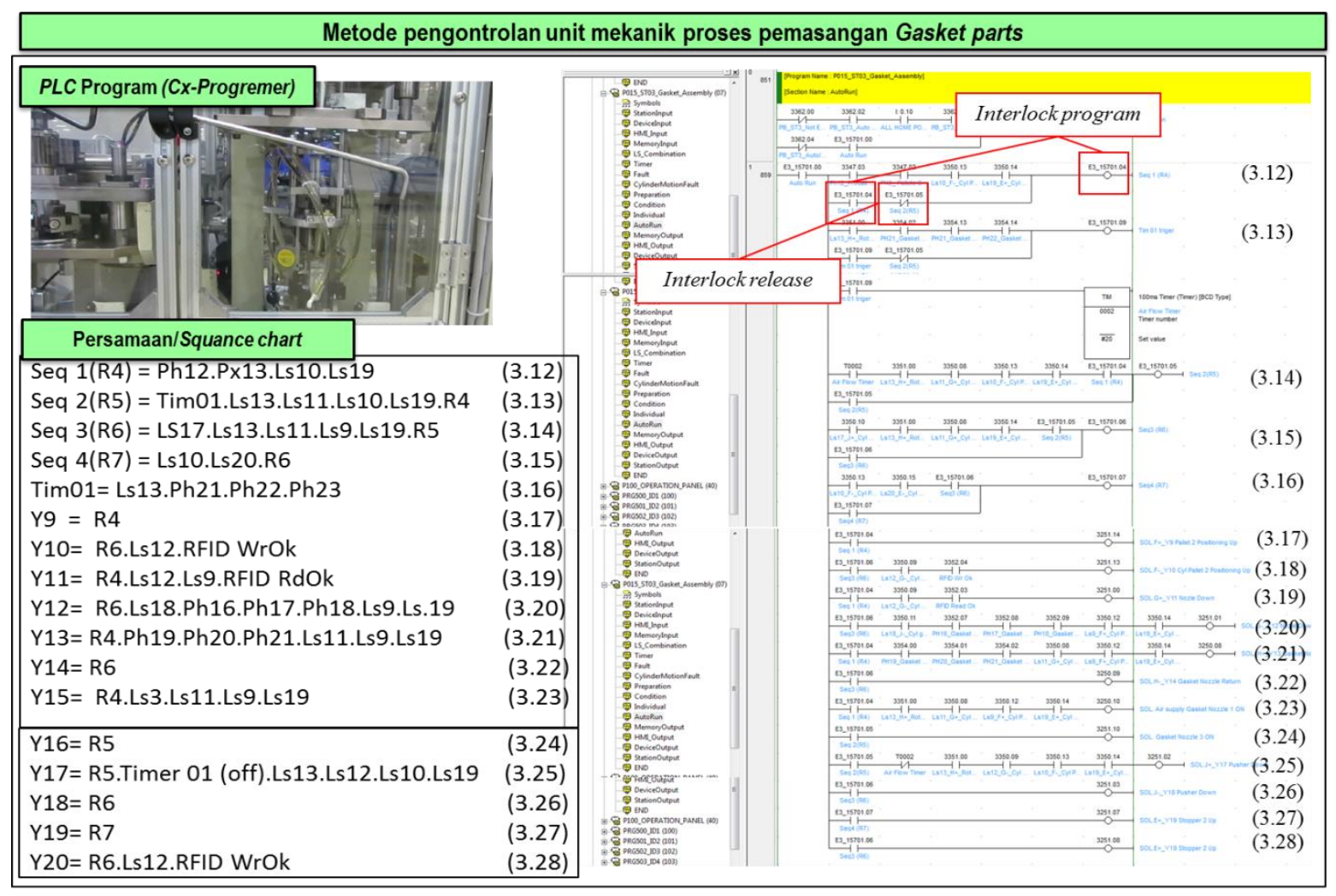

\section{Hasil dan Pembahasan}

Gambar 13. PLC program otomatis pemasangan gasket parts

Setelah melalui tahap pembuatan, tahap instalasi, hingga diputuskan bahwa mesin dapat digunakan untuk proses mass production, langkah selanjutnya adalah proses spesial monitoring selama mass production, dimana pada kondisi mass production dengan adanya penambahan proses otomatis pada proses gasket assembling, kondisi line operation ratio tidak boleh kurang dari target, yang mana target line operation ratio pada saat mass production adalah sebesar $87 \%$, untuk line preparation dan measuring sebesar $3 \%, N G$ pada proses sebesar 1,2\%, Chokotei/Short stop sebesar $3 \%$, mesin breakdown sebesar $2 \%$, persiapan perubahan model sebesar $1,5 \%$ dan cycle time lost sebesar $2,3 \%$.

\subsection{Kondisi Mesin Saat Running Mass Production}

Proses pemantauan dilakukan sejak hari pertama mesin gasket assembling digunakan untuk mass production yaitu pada tanggal 20 Febuari 2017, dimana pada proses pemantauan/monitoring ini penulis hanya melakukan perhitungan pada mesin gasket assembling short stop, mesin gasket assembling break down, dan total line operation ratio. Sedangkan untuk item line preparation, quality check, penanganan not good produk, dimasukkan pada item CT lost begitu pula dengan item persiapan perubahan model karena jumlah waktu persiapan perubahan model pada setiap harinya kurang lebih akan sama, hal ini disebabkan karena belum adanya penambahan model baru, sehingga untuk nominal besarnya persentase persiapan perubahan model setiap harinya dianggap sama.

Pada Gambar 13 digambarkan ringkasan dari proses monitoring gasket assembling machine selama 2 shift produksi, dimana shift 1 dilakukan sejak pukul 7.30 sampai dengan 16.30 apabila ada overtime maka hingga 20.00 atau dengan kata lain 8 sampai dengan 11 jam kerja setelah dikurangi waktu istirahat, sedangkan shift 2 dilakukan sejak pukul 21.00 hingga pukul 06.00 apabila ada overtime hingga pukul 07.00 atau dengan kata lain 8 sampai dengan 10 jam kerja setelah dikurangi waktu istirahat, dan untuk proses pencatatan dilakukan oleh leader dari line clutch sub assy starter apabila terjadi kondisi tidak normal pada mesin, selanjutnya setiap harinya production engineering akan melakukan summary dan analisa terhadap masalah yang terjadi dari data-data yang telah dicatat oleh leader. Dalam satu shift produksi selama 8 jam kerja rata-rata produk yang dihasikan sebanyak 1670 sampai dengan 1740 buah starter assy, dan proses pemantauan ini dilakukan sejak tanggal 20 Febuari 2017 sampai dengan tanggal 23 Febuari 2017.

Pada hari pertama di tanggal 20 Febuari 2017 terjadi break down mesin, yang mana disebabkan karena terjadinya kerusakan komponen kontaktor pada mesin, yang kemudian dilakukan 
perbaikan penggantian komponen tersebut, sedangkan pada hari-hari selanjutnya banyak terjadi short stop yang diakibatkan karena gasket tidak dapat dialirkan ke bagian nozzle, baik nozzle 1, 2 atau pun 3 , sehingga setelah production engineering melakukan analisa selama empat hari, di hari ke empat production engineering melakukan kordinasi meeting dengan machinery, maintenance dan produksi departmen untuk menyampaikan konsep improvement dan saling bertukar pendapat agar mendapatkan item perbaikan yang mampu menyelesaikan masalah hingga ke akar masalah, dengan menggunakan metode $5 \mathrm{M}+1 \mathrm{E}$ dan Why, Why, Why dimana untuk analysis $5 \mathrm{M}+1 \mathrm{E}$ terdiri dari Man, Machine, Material, Methode, Money dan Environmental, sehingga dengan menggunakan metode-metode diatas akhirya didapatkan kesimpulan bahwa pada proses otomasi gasket assembling hanya ada dua kemungkinan, yaitu material dan machine, oleh karena itu langkah pertama adalah melakukan pengukuran terhadap dimensi dari material gasket, setelah dilakukan pengukuran dan ternyata hasil dimensi material gasket tersebut masih di dalam range standard drawing, maka masalah selanjutnya yang harus dianalisa adalah mesin gasket assembling, untuk menganalisa suatu item mengapa masalah itu terjadi kita memikirkan kemungkinan-kemungkinan penyebabnya hingga pertanyaan why minimum sebanyak tiga kali, maka dengan metode tersebut diharapkan dapat menemukan masalah hingga penyebab yang paling dalam atau disebut juga hingga ke akarnya.

Gambar 14 menunjukkan hasil dari proses analisa masalah-masalah yang terjadi selama proses monitoring dan proses improvement yang dilakukan, dimana untuk item improvement tidak semua item dapat segera direalisasikan terkait adanya proses pembuatan komponen yang membutuhkan waktu. Oleh karenanya dilakukan pembagian waktu improvement dimana item pembuatan komponen yang mudah dibuat didahulukan proses dan pemasanganya pada hari minggu tanggal 26 Febuari 2017, sehingga pada tangal 27 Febuari 2017 perbaikan dari LOR clutch line dapat terlihat dan untuk komponen yang lainya dilakukan pemasangan pada tanggal 1 Maret 2017 , sehingga dengan semua item improvement telah terlaksana dapat dilihat kondisi LOR dari starter clutch line pada Gambar 14 sejak tanggal 1 Maret 2017 dimulai dari proses produksi pada shift 2 kondisi LOR dari

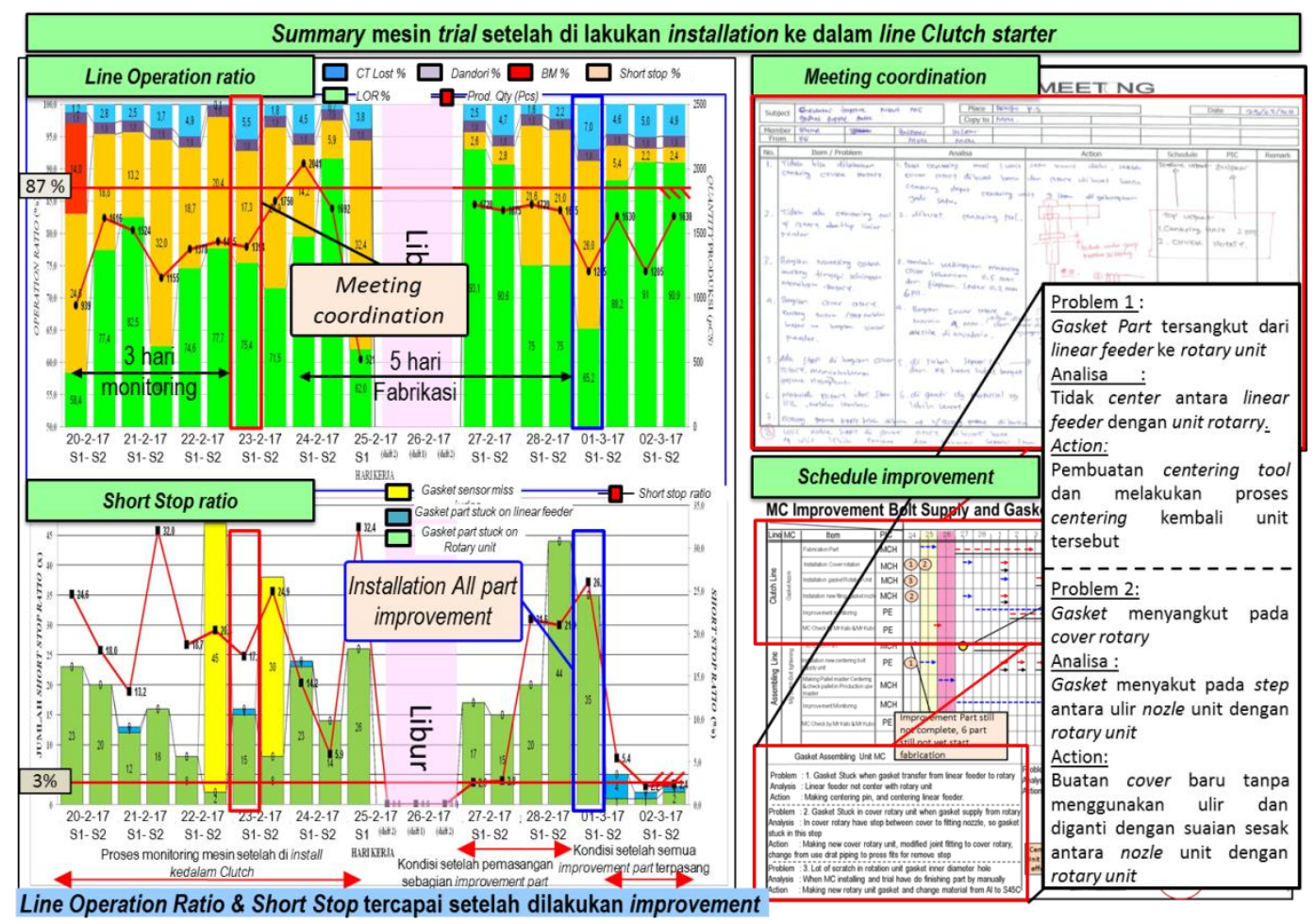

Gambar 14. Analisis dan penyelesaian masalah beserta jadwal perbaikan

\subsection{Efek Pemasangan Mesin Gasket Assembling}

Starter clutch line menerapkan sistem flexible cycle time line, dimana diantaranya adalah 10 detik, 13 detik dan 15 detik, dimana pengaturan cycle time line ini berdasarkan dari jumlah volume permintaan pelanggan setiap bulannya. Untuk volume permintaan pelanggan sudah dikirimkan oleh pelanggan untuk kurun waktu 6 bulan kedepan. 
Pada Gambar 15 dapat dilihat dengan kondisi flexible cycle time line 10 detik, 13 detik dan 15 detik dengan di install nya mesin otomatis gasket assembling pada clutch line dapat menurunkan 1 orang operator disetiap masing-masing cycle time yang sedang digunakan, hanya saja pada cycle time line 13 detik dan 15 detik harus dilakukan proses balancing item-item kerja operator setelah proses gasket assembling dilakukan secara otomatis. Sedangkan untuk cycle time line 10 detik dapat langsung mengurangi operator tanpa harus dilakukan proses balancing.

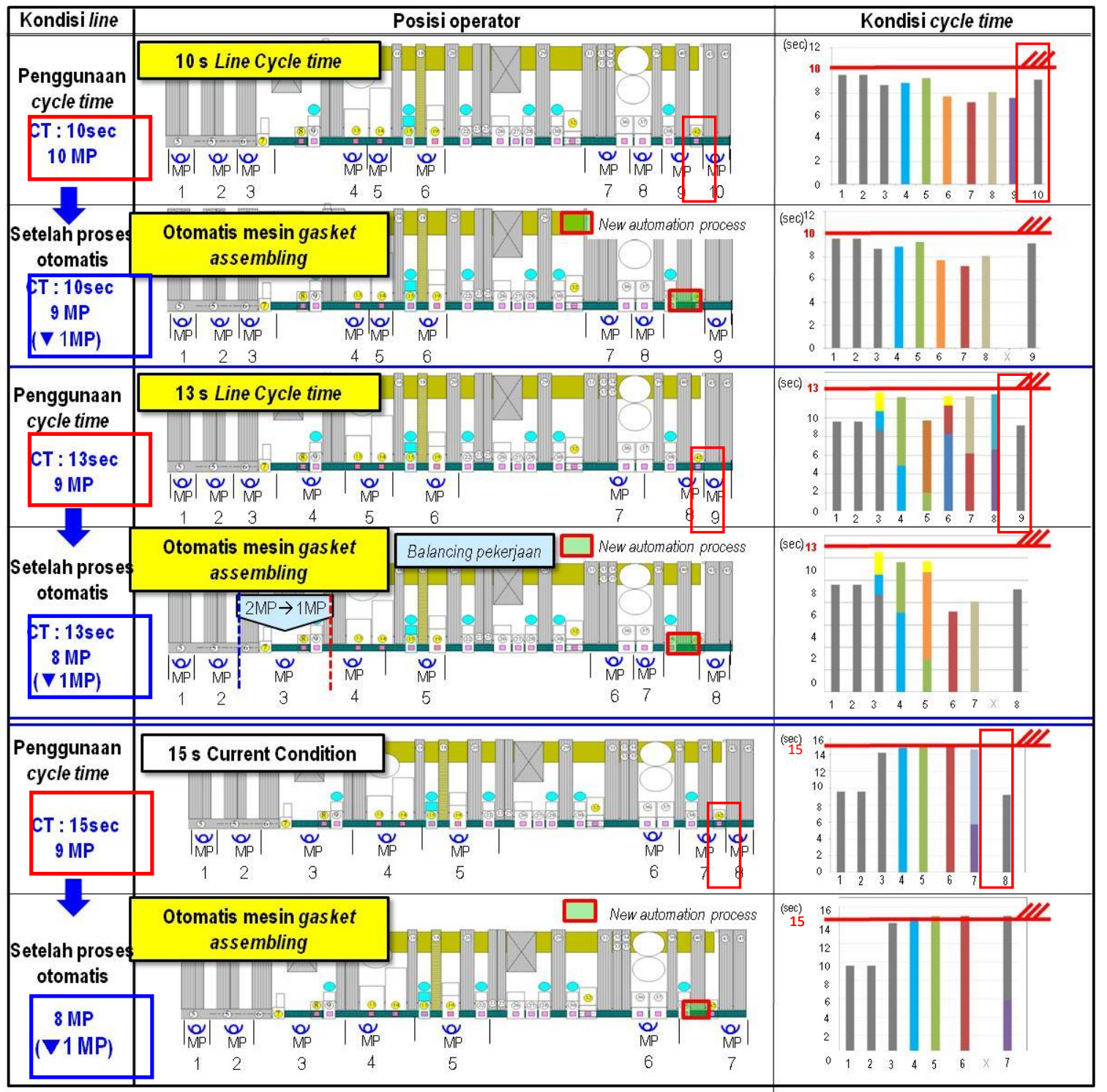

Gambar 15. Hasil instalasi otomatis mesin gasket

Dengan berkurangnya 1 orang operator pada proses produksi, maka hal ini memberikan keuntungan bagi perusahaan karena kebutuhan man hour dalam proses pembutan clutch sub assy starter semakin berkurang, disini penulis akan menggunakan sample pada saat clutch sub assy line menggunakan cycle time 15 detik, metode perhitungan ini berlaku pula untuk kondisi cycle time 10 detik dan 13 detik, dimana dengan mengunakan Persamaan (1) berikut maka kita dapat mengetahui kebutuhan man hour dalam proses pembuatan produk.

$$
\text { Man Hour }=\frac{\text { Net time } \mathrm{X} \text { Jumlah produksi }}{\text { Operation Ratio } \times 3600}
$$

Dengan mengasumsikan jumlah produk yang harus dibuat dalam satu shift adalah sebesar 1.670 pcs maka kita dapat mengetahui perbedaan man hour yang dibutuhkan antara sebeum proses otomasi dan setelah proses otomasi. 
Man Hour Clutch Line Sebelum Otomasi

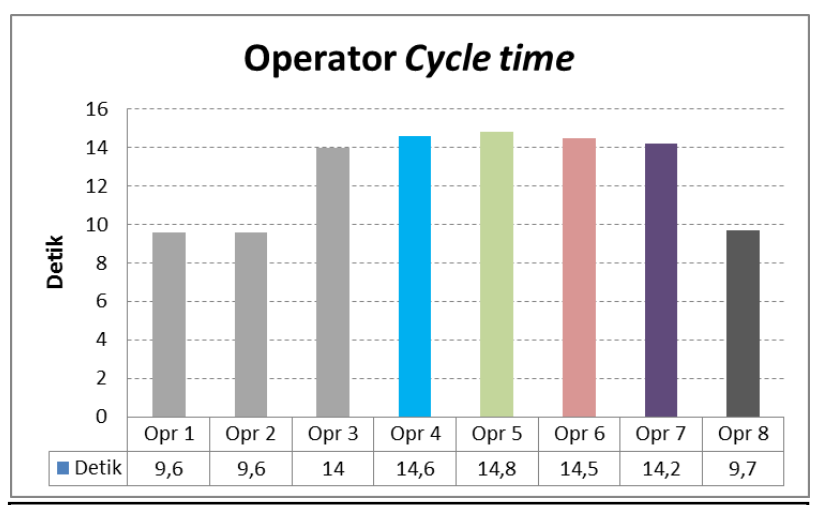

Net Time $=$ Waktu yang dibutuhkan untuk membuat 1 buah produk jadi.

= Ct Opr $1+$ Ct Opr $2+$ Ct Opr $3+\ldots+$ Ct Opr n

Net Time $=9,6+9,6+14+14,6+14,8+14,5+14,2+9,7$

$=101$ detik

Man hour $=\frac{101 \times 1670}{87 \% \times 3600}=53,85$

\section{Man Hour Clutch Line Setelah Otomasi}

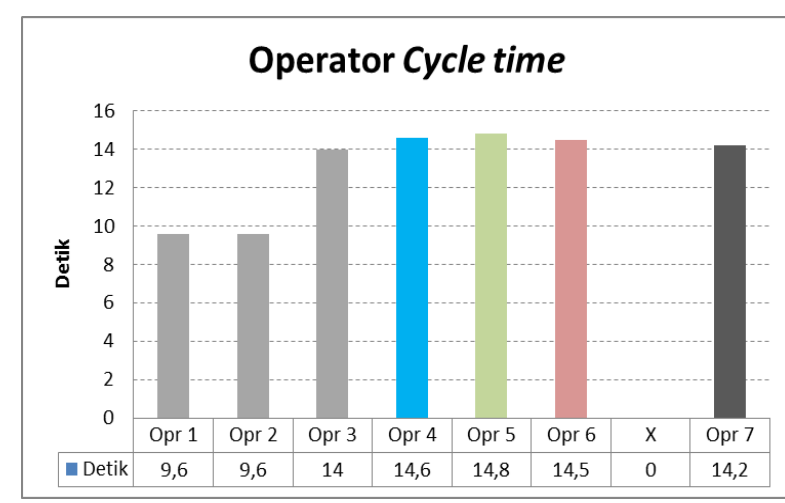

Net Time $=$ Waktu yang dibutuhkan untuk membuat 1 buah produk jadi.

= Ct Opr 1+Ct Opr $2+$ Ct Opr $3+. .+$ Ct Opr n

Net Time $=9,6+9,6+14+14,6+14,8+14,5+14,2$

$=91,3$ detik

Man hour $=\frac{91,3 \times 1670}{87 \% \times 3600}=48,68$

Dengan demikian terjadi penurunan man hour sebanyak 53,85- 48,68 = 5,17 di dalam satu shift produksi, karena Starter Line beroprasi dalam 2 shift maka total man hour saving sebesar 10,34.

Berdasarkan data yang didapatkan dari department business planning estimasi untuk membayar satu operator perjam adalah sebesar Rp. 77.292,00 (untuk detail perhitungan merupakan data yang dirahasiakan oleh perusahaaan) sehingga total biaya yang dihemat oleh perusahaan adalah sebesar Rp. $77.292,00 \times 10,34=$ Rp. 799.199,28 dalam 2 shift produksi perhari, apabila didalam satu bulan terdapat minimum 20 hari kerja maka total biaya yang dihemat oleh perusahaan adalah sebesar Rp. $799.199,28 \times 20=$ Rp. $15.983 .986,60$.

\subsection{Break Even Point Pembuatan Mesin Otomatis Gasket Assembling}

Untuk mengubah proses dari manual menjadi otomatis dibutuhkan investasi biaya dalam proses perubahannya. Pada hal ini perusahaan mengalokasikan dana sebesar Rp. 220.000.000,00 yang mana nominal ini merupakan pendekatan dari konversi biaya yang dikeluarkan oleh perusahaan dalam membayar seorang operator selama 2 tahun masa kerja. Angka tersebut diantaranya terdiri dari gaji pokok, tunjangan transportasi, tunjangan makan, tunjangan pengobatan, biaya overtime kira-kira 40 jam per bulan dan lain sebagainya, sehingga apabila starter line beroperasi dengan 2 shift maka untuk pembuatan mesin otomastis gasket assembling ini perusahaan menyediakan budget sebesar Rp. 440.000.000,00.

Pada Gambar 16 ditunjukkan penawaran harga mesin/machine quotation dari machine maker (machinery department) dimana penawaran harga dari machine maker sebesar Rp. 377.620.000,00 ,dimana harga tersebut terdiri dari beberapa bagian, (1) manufacturing part (biaya bahan baku komponen), (2) manufacturing cost (biaya proses pembuatan komponen) (3) Purchase cost (biaya pembelian komponen jadi), (4) Advance stock adalah biaya untuk pembuatan stok produk, (5) Administration merupakan biaya proses design dan assembling, (6) Over head adalah biaya fluktuasi harga pembelian komponen, karena pada saat pembuatan estimasi harga di pasaran dapat sewaktuwaktu berubah karena adanya jeda waktu antara proses order dengan penawaran yang dikeluarkan, akan tetapi setelah proyek pembuatan mesin otomatis gasket assembling selesai aktual biaya yang dibutuhkan hanya sebesar Rp. 356.400.000,00 lebih rendah sebanyak Rp.21.220.000,00. 


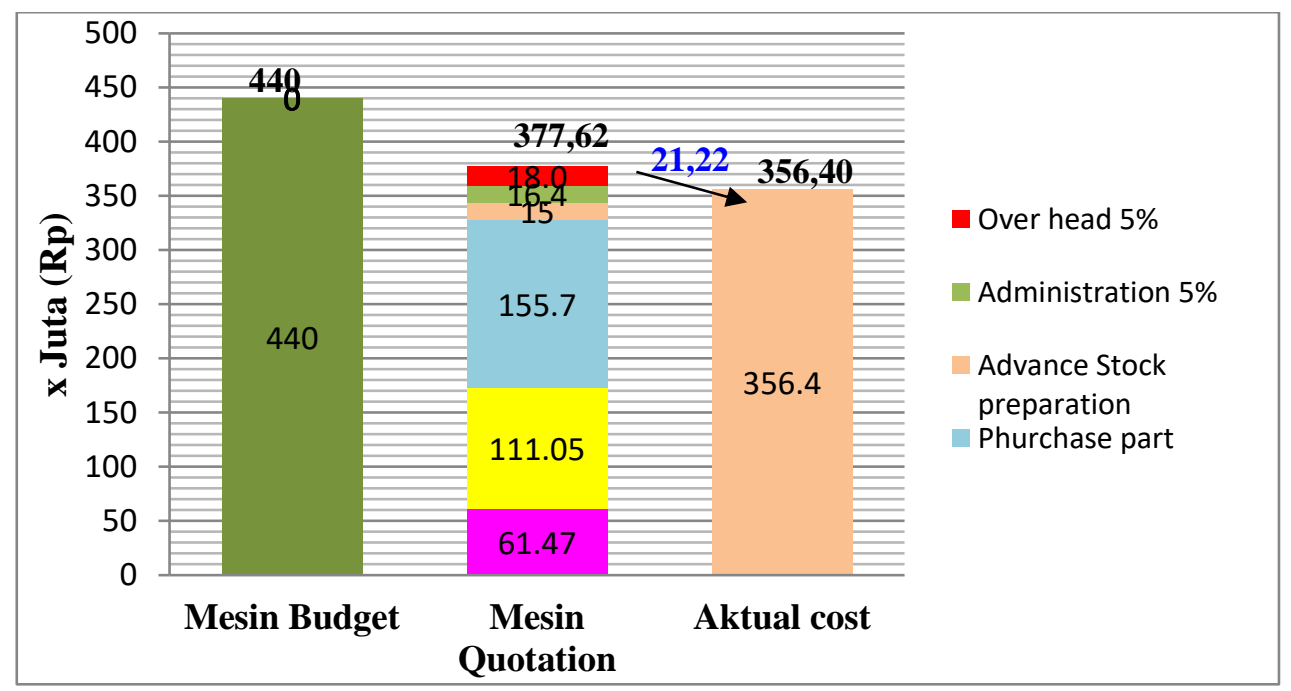

Gambar16. Biaya pembuatan mesin gasket assembling

Setelah diketahui biaya investasi dalam pembuatan otomatis mesin dan pendapatan yang diperoleh bagi perusahan dengan dilakukanya perubahan proses manual gasket assembling menjadi proses otomatis, dengan mengunakan Persamaan (2) yang diambil dari Hafizh (2015), akan diketahui kapan waktu dari Break Even Point/Return Of Investment dari biaya investasi yang telah dikeluarkan untuk pembuatan mesin otomatis gasket assembling.

$$
B E P \text { unit }=\frac{F C}{P-V C}
$$

Dimana :

$\mathrm{FC}=$ Fixed Cost [4]; terdiri dari biaya investasi pembuatan otomatis mesin gasket assembling.

$\mathrm{VC}=$ Variable cost $[4]$; terdiri dari :

1. Biaya man hour cost line setelah dilakukannya perubahan manual proses menjadi otomatis proses gasket assembling,

2. Biaya perawatan serta operasional dari mesin,

3. Biaya bahan baku produksi,

4. Biaya Tool dan keperluan utility produksi,

5. Biaya Lainya (ex: Indirect cost).

$\mathrm{P}=$ Harga jual produk; Harga jual Clutch Sub Assy Starter produk

Asumsi :

Jumlah produk perhari $=1.670$ pcs

$\mathrm{FC}=$ Rp. 356.400.000,00

$\mathrm{VC}=$ Rp. 32.552.143,00:1.670 pcs/shift $=$ Rp. $19.492,30 /$ pcs.

(detail dapat dilihat pada table 3.1)

$\mathrm{P}=$ Rp. 20.000,00 /pcs (clutch sub assy starter produk)

Rp. $20.000,00 / p c s \times 1670$ pcs $/$ shift $=$ Rp. $33.400 .000,00 /$ shift .

Sehingga BEP akan terjadi pada saat jumlah produksi mencapai:

$$
B E P \text { unit }=\frac{F C}{P-V C}=\frac{R p \cdot 356 \cdot 400 \cdot 000,00}{R p \cdot 20 \cdot 000,00-R p \cdot 19 \cdot 492,30}=701 \cdot 989,36 \text { Pcs prodak }
$$

dengan demikian BEP dari pembuatan mesin otomatis gasket assembling akan tercapai dalam waktu:

$$
\begin{gathered}
\text { Hari }=\frac{701.989,36 \text { Pcs prodak }}{\left(1.670 \frac{\text { pcs }}{\text { shift }} \times 2 \text { shift }\right)}=210,18 \text { hari } \\
\text { Bulan }=\frac{210,18 \text { hari }}{20 \text { hari kerja }}=10,51 \text { Bulan }=0,88 \text { Tahun }
\end{gathered}
$$


Setalah titik BEP dari perubahan proses manual gasket assembling menjadi otomatis gasket assembling proses tercapai maka prusahaan akan mendapatkan profit dari setiap produk yang terjual sebesar:

$$
\text { Prof it setelah otomasi }=R p .20 .000,00-R p .19 .492,30=R p \cdot 507,70 / p c s
$$

Sedangkan profit yang didapat sebelum perubahan proses otomasi gasket assembling adalah sebesar:

$$
\text { Profit sebelum otomasi }=R p \cdot 20.000,00-R p \cdot 19.731,50=R p \cdot 268,50 / p c s
$$

Hal ini diperoleh dari penurunan biaya man hour cost sebesar Rp. 239,20/pcs setelah proses gasket assembling dilakukan secara full otomatis.

\begin{tabular}{|c|c|c|c|c|c|c|}
\hline \multicolumn{3}{|r|}{ Item } & $\begin{array}{c}\text { Presentase } \\
\text { (\%) }\end{array}$ & Satuan & Nominal & Total \\
\hline \multicolumn{3}{|c|}{ Jumlah Produksi } & ـ & $p C s$ & - & $1670 /$ shift \\
\hline \multicolumn{3}{|r|}{ Fix Cost } & - & $\mathrm{Rp}$ & - & $356.400 .000,00$ \\
\hline \multirow{6}{*}{$\begin{array}{c}\text { Variable } \\
\text { Cost }\end{array}$} & 1 & Biaya Operator & 11,56 & Rp & $2.253,12$ & - \\
\hline & 2 & Biaya Operasional mesin & 10,84 & $\mathrm{Rp}$ & $2.112,44$ & - \\
\hline & 3 & $\begin{array}{l}\text { Biaya Bahan baku } \\
\text { produksi }\end{array}$ & 55,43 & $\mathrm{Rp}$ & $10.804,60$ & - \\
\hline & 4 & Biaya tool produksi & 10,89 & $\mathrm{Rp}$ & $2.122,15$ & - \\
\hline & 5 & Biaya Lainya & 11,29 & $\mathrm{Rp}$ & $2.200,00$ & - \\
\hline & & Total & 100 & $\mathrm{Rp}$ & - & $19.492,30$ \\
\hline \multicolumn{3}{|c|}{ Harga Produk/Pcs } & - & $\mathrm{Rp}$ & - & $20.000,00$ \\
\hline \multicolumn{4}{|c|}{ BEP unit } & PCS & - & $701.989,36$ \\
\hline \multicolumn{4}{|c|}{ Waktu } & Hari & 3.340 pcs & 210,18 \\
\hline & & & & Bulan & $\begin{array}{c}20 \text { Hari } \\
\text { kerja }\end{array}$ & 10,51 \\
\hline & & & & Tahun & & 0,88 \\
\hline \multicolumn{4}{|c|}{ Profit / pcs produk } & $\mathrm{Rp}$ & & 507,70 \\
\hline
\end{tabular}

Tabel 2 Ringkasan Perhitungan BEP

Gambar 17 merupakan grafik dimana titik BEP terjadi (tercapai), yakni titik potong antara besarnya jumlah produk yang harus dibuat dan besarnya nilai rupah yang dikeluarkan untuk membuat produk. Dengan menggunakan Persamaan (3) yang diambil dari Hafizh (2015) kita dapat mengetahui berapa besar nilai rupiah yang harus dikeluarkan hingga tercapainya titik BEP:

$$
\begin{gathered}
\text { BEP nilai }=\frac{F C}{1-\frac{V C}{P}} \\
B E P=\frac{R p \cdot 356 \cdot 400 \cdot 000,00}{1-\frac{R p \cdot 19 \cdot 492,30}{R p \cdot 20 \cdot 000,00}}=R p \cdot 14 \cdot 039 \cdot 787 \cdot 275,95
\end{gathered}
$$

Sedangkan pada Tabel 3 menggambarkan hubungan antara jumlah produk yang dibuat dengan besarnya nilai variable cost dan total cost (Wahab, 2011) yang dikeluarkan hingga akhir nya mencapai titik BEP. 
Tabel 3 Kalkulasi total revenue

\begin{tabular}{|c|c|c|c|c|c|}
\hline & Rp. X 1.000 .000 \\
\hline Qty Produk & Fix cost & Variable cost & Total cost & $\begin{array}{c}\text { Total } \\
\text { revenue }\end{array}$ & Profit \\
\hline 1 & 356,40 & 0,019 & 356,419 & 0,020 & $-356,39949$ \\
\hline 2 & 356,40 & 0,039 & 356,439 & 0,040 & $-356,39898$ \\
\hline 3 & 356,40 & 0,058 & 356,458 & 0,060 & $-356,39848$ \\
\hline I & 1 & 1 & 1 & $\begin{array}{l}1 \\
1\end{array}$ & 1 \\
\hline$\frac{1}{1}$ & $\frac{1}{1}$ & $\frac{1}{1}$ & i & i & i \\
\hline 7 & 7 & 7 & $\boldsymbol{t}$ & $\boldsymbol{t}$ & 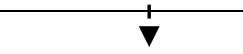 \\
\hline 701.986 & 356,40 & $13.683,329$ & $14.039,729$ & $14.039,727$ & $-0,00152$ \\
\hline 701.987 & 356,40 & $13.683,348$ & $14.039,748$ & $14.039,747$ & $-0,00102$ \\
\hline 701.988 & 356,40 & $13.683,368$ & $14.039,768$ & $14.039,767$ & $-0,00510$ \\
\hline 701.989 & 356,40 & $13.683,387$ & $14.039,787$ & $14.039,787$ & 0,00000 \\
\hline 701.990 & 356,40 & $13.683,407$ & $14.039,807$ & $14.039,807$ & 0,00051 \\
\hline 701.991 & 356,40 & $13.683,426$ & $14.039,826$ & $14.039,827$ & 0,00102 \\
\hline
\end{tabular}

Nilai (Rp)

dalam Juta

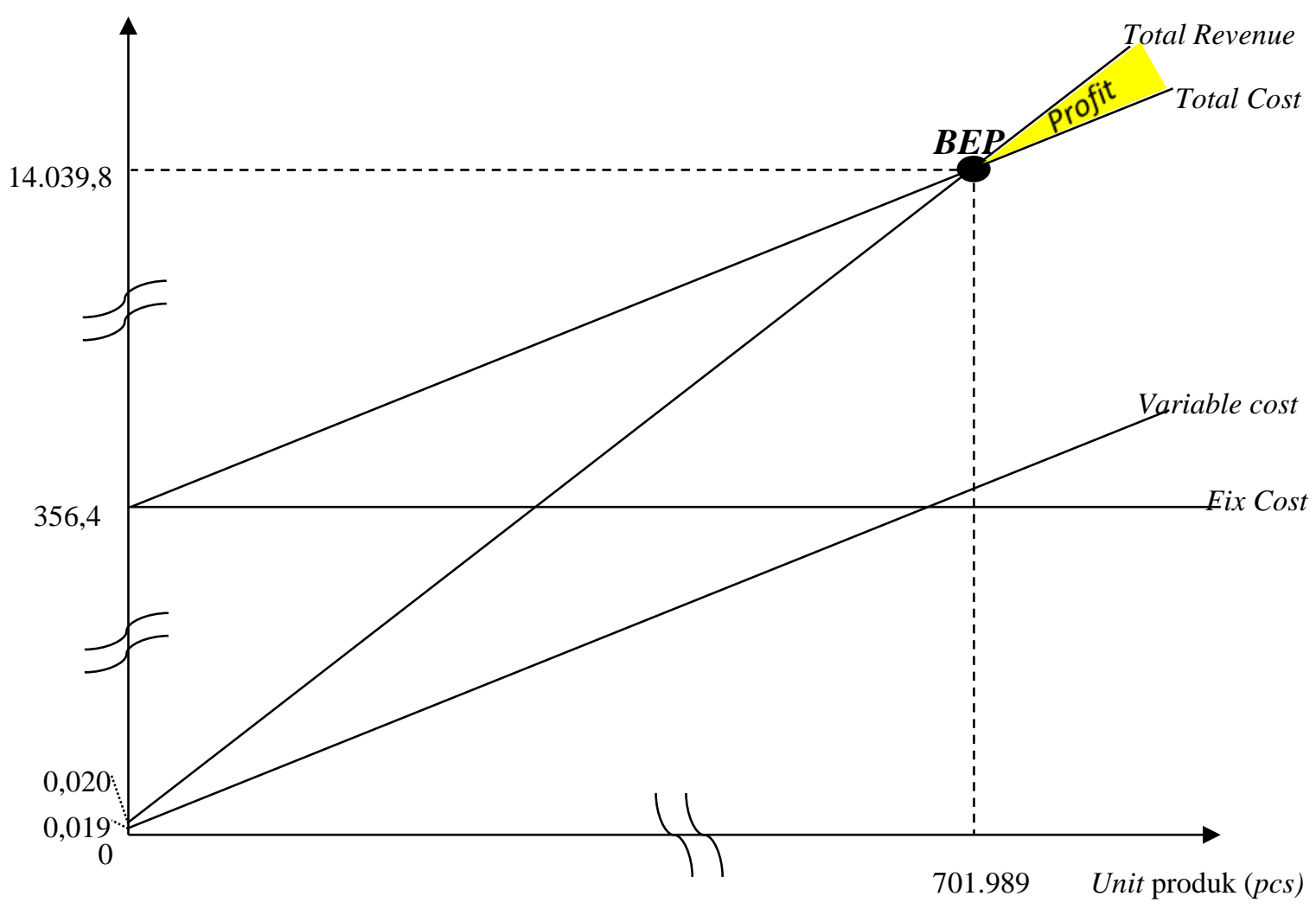

Gambar 17. Grafik titik BEP pembuatan otomatis mesin gasket assembling

\section{Simpulan}

Dari hasil pembuatan, instalasi dan running mass production full otomatis mesin gasket assembling dapat diambil simpulan sebagai berikut:

1. Proses pemasangan gasket part ke case bearing $S / A$ dapat dilakukan dengan proses full otomatis, dengan hasil proses capability memenuhi target stadar.

2. Proses pengarahan pin barrel sejauh $35^{\circ} \pm 5^{\circ}$ dapat dilakukan dengan proses full otomatis, dengan hasil proses capability memenuhi target stadar. 
3. Dengan dibuatkannya full otomatis mesin gasket assembling untuk menggantikan proses manual gasket assembling dapat meningkatkan profit perusahaan, dimana dengan menggunakan full otomatis mesin gasket assembling dapat mengurangi 1 operator di setiap shift produksi, dan akan menghasilkan profit untuk perusahaan Rp. 507,70/pcs produk setelah titik BEP tercapai dalam waktu 10,50 bulan semenjak mesin digunakan untuk mass production dengan minimal jumlah produksi per shift sebanyak 1670 pcs clutch sub assy starter.

4. Dengan penggunaan full otomatis mesin gasket assembling tingkat kesalahan proses, dalam hal ini yang bersangkutan dengan kualitas produk yaitu jumlah gasket yang terpasang dan posisi dari pin barrel, apabila terjadi hasil yang diluar standar dapat dideteksi oleh mesin sehingga mengalirnya produk yang not good ke proses selanjutnya dapat dicegah sebanyak $100 \%$.

5. Setelah dilakukan proses monitoring dan dilakukanya perbaikan pada full otomatis mesin gasket assembling, line operation ratio dan short stop ratio dapat mencapai target yaitu > $87 \%$ untuk line operation ratio dan $<3 \%$ untuk short stop ratio.

Penulis berharap berdasarkan dari smpulan-simpulan yang telah didapat, hal-hal yang menjadi pertanyaan pada Bab 1 sudah dapat terjawab.

Untuk dapat meningkatkan kualitas dalam proses pembuatan mesin/proses otomasi di kemudian hari, berdasarkan dari proses pembuatan, instalasi dan running mass production dengan menggunakan full otomatis mesin gasket assembling maka dapat diambil beberapa rekomendasi, diantaranya :

1. Pada pembuatan-pembuatan full otomatis mesin yang selanjutnya ditambahkan proses pembuatan proto dari sistem utama pada proses, dengan tujuan masalah-masalah yang akan terjadi pada kondisi mass production dapat terdeteksi lebih dini secara aktual.

2. Untuk machine maker / machinery department harus benar benar memperhitungkan waktu dalam proses pembelian parts standar atau pun elektrikal parts, karena apabila kedatangan parts tersebut tidak sesuai dengan target hal, ini akan berpengaruh terhadap schedule yang lainnya, yaitu berkurangnya schedule dalam proses assembling mesin atau bahkan akan mempengaruhi schedule proses trial hingga schedule instalasi.

Berdasarkan dari saran-saran yang telah disampaikan, penulis berharap pada proses pembuatan mesin otomatis selanjutnya akan menjadi lebih baik lagi.

\section{Daftar Pustaka}

1. Gorlach, I. (2008), Optimal Level of Automation in the Automotive Industry, Engineering Letters, 16:1, EL_16_1_21.

2. Hafizh M. Rumus BEP dan Mengenal BEP Secara Lengkap, Diambil dari http://www.bisnisrumahanpemula.com/rumus-bep/ pada tanggal 15 Februari 2018.

3. Hendy, R., Class Lecture, Topic: Programmable Logic Contoller, Mekatronika, Politeknik Manufaktur Negeri Bandung, Jawa Barat, Oct. 10, 2008.

4. Mohamed, N.M.Z.N, et al., (2005). Manpower Consideration, to Reduce Development Time for New Model in Automotive Industry, American Journal of Applied Sciences 2(4): 763-767.

5. Sulaeman D., Class Lecture, Topic: Kontrol Pneumatik, Mekatronika, Politeknik Manufaktur Negeri Bandung, Jawa Barat, Jan. 31, 2009.

6. Wahab, A. Jenis-Jenis Biaya. Pp.1-3, 2011. Diambil dari https://wahabxxxxx.files.wordpress.com/2011/10/biaya.pdf pada tanggal 15 Februari 2018. 